\title{
Engendering the Aesthetics of Solidarity in Lina Magaia's Dumba Nengue
}

\section{Hilary Owen}

\begin{abstract}
Este artigo analisa Dumba Nengue, a colecção de histórias editada por Lina Magaia em 1987, no contexto da guerra Renamo/Frelimo em Moçambique. Seguindo as teorias de testemunho do crítico George Yúdice pensadas no contexto latino-americano, analiso aqui a maneira como Magaia utiliza uma estética narrativa de solidariedade para construir uma imagem da nação frelimiana, baseada nos ideais da aldeia comunal, familia e lar, ligados nesta instância pela experiência de sofrimento em comum e pela necessidade de defender o "corpo" comunal da aldeia/nação. Dentro deste contexto, a figura materna exemplificada pela persona de Lina Magaia, desempenha um papel ético, social e metonímico, disseminando o poder da subjectividade e da fala, para interpelar o povo num novo conjunto nacional depois da morte do Presidente Samora Machel, em 1986.
\end{abstract}

\begin{abstract}
A identidade moçambicana é, de certa forma, uma herança que herdámos da coragem e da valentia de muitos homens e mulheres que lutaram, que se sacrificaram e dos quais muitos morreram pela nossa independência, pela nossa soberania, pela nossa liberdade.

(Severino Elias Ngoenha, 17).
\end{abstract}

Dumba Nengue. Histórias Trágicas do Banditismo, Lina Magaia's collection of testimonial accounts detailing Renamo attacks on the southern Mozambican peasantry, is one of the best internationally known texts to have emerged from Mozambique during the period of the Frelimo/Renamo conflict in the 1980s and early 1990s. Drawn from Magaia's own experiences and those narrated to her by peasants and plantation workers in Manhiça, where she became Director of Agricultural Develoment in 1986, ${ }^{1}$ these narratives performed a variety of functions, in relation to their different readerships. At different points in the war, they acted as national consolidation discourse, war refugee testimonial, and a Frelimo attempt at blocking moves towards international pro-RENAMO solidarity. The accounts were published in three major formats and contexts. Initially conceived and published by Magaia as journalistic "crónicas", rather than as direct news reporting, they appeared in the "Aspectos da guerra" series of the Maputo weekly news review Tempo. Following the death of the President Samora Machel in October 1986 in a controversial plane crash widely blamed on South Africa, the Tempo chronicles and other similar accounts not originally part of the Tempo series, were published in a single, expanded volume entitled Dumba Nengue. Histórias Trágicas do Banditismo. ${ }^{2}$ This book version appeared in mid-1987 in Tempo's "depoimentos" book series, with a "dedicatória" to Magaia's own parents and to Samora Machel. Apart from Magaia's first person introduction, and some first person plural accounts of events she witnessed, the stories are edited, mediated and retold in the third person as the testimonies of "populações analfabetas e sem condições de radiodifusão ou outro meio 
técnico para informarem sobre o seu dia-a-dia" (6). Responding to a moment of crisis, Dumba Nengue became a popular success with a Mozambican reading public, acting as an exhortative vox populi, which integrated the specific hostilities of the present with Frelimo's heroic, foundational discourses from the past and called on people's militias to undertake the defence of the "pátria."

In 1988 the translation of the work into English by Michael Wolfers for publication in the USA with an historical introduction by Allen Isaacman brought the collection into the international arena of anti-Renamo campaigns, Frelimo solidarity, and refugee studies, particularly in North America. This ensured the book's status as the Mozambican text about the war, which was most widely circulated outside the country. ${ }^{3}$ Focusing rather on the original Portuguese and on the implications of its female-voicing, I contend that Dumba Nengue uses narrative techniques associated with testimonial writing, to explore the flexibility of socially gendered signifiers, such as the maternal and the home in the discursive construction of imagined nationhood. One obvious effect of this is Magaia's Marxist reworking of maternal figuration in a primarily socio-symbolic sense, effectively distancing it from the essentialist "Mãe Negra" embodiments characteristic of African nationalist poetics, in keeping with Frelimo's gender neutralisation of embodiment per se in its figuration of state unity. As Magaia adapts the interpellative strategies of her testimonial chronicles to the purposes of national consolidation discourse, heightened by the limit situation of war, she goes some way to appropriating and transforming the discursive field of the "family as nation" to afford individual women active, specific and expressive roles in her putatively regenerative national script. As Anne McClintock has pointed out in her study of women organizing in South African nationalism, the ideology of motherhood has remained a powerful axis of identification and mobilization but its meanings are not fixed or constant: "Motherhood is less the universal and biological quintessence of womanhood than it is a social category under constant contest. African women have embraced, transmuted and transformed the ideology in a variety of ways, working strategically within traditional ideology to justify untraditional public militancy" (381).

As a high profile, office-holding Frelimo woman, Magaia had risen largely through her work in the party women's movement, the OMM, constituting a fairly unusual success story in Frelimo's widely criticized and contingent strategies regarding women's liberation. ${ }^{4}$ In And Still they Dance, Stephanie Urdang who worked with Lina Magaia in Mozambican women's projects in the 1980s writes, "Lina: educated, a writer, a leader, responsible for a district agricultural program, is pushing to extend Frelimo's commitment to equality, even as she exemplifies it" (And Still they Dance 243). Magaia's grounding in Frelimo women's organizations and her own continued belief in women's equality agendas inform, but do not necessarily constrain, her negotiation of the subject positions available to her, within and beyond the possibilities offered by Frelimo, in making nationhood speak to a people, made up of women and men, increasingly disconnected from any meaningful experience of state authority. As a contextual prelude to this analysis, it is useful to revisit briefly the specific conditions, which determined and impeded Mozambique's post-independence attempts at national consolidation in the Cold War context.

The foundational discourses of Mozambique's National Independence Struggle were largely reactive, a form of anti-colonial self-reinvention through a consciousness of oppression. ${ }^{5}$ In the post-independence period, the state's forward-thinking, anticipative strategies of popular identification and appeal were couched mainly in the political discourse of class struggle and voluntarism, directed by the leadership of Frelimo as urban, intellectual vanguard party. As a revolutionary movement Frelimo had been primarily concerned with anti-imperialism and class relations, and had largely adopted pre-existing liberal Enlightenment models of nationhood. Carlos Serra, for example, has referred to the 
"discurso 'jacobino' frelimiano" which constructed an intransigently oppositional "moçambicanidade" as "um dever-ser absoluto, irredutível e cidadão, que não devia ser contaminado pelas invasões parasitárias do étnico" (11). The emphasis on principles of duty and citizenship rather than race and ethnic differences, was to remain, as it had been under Eduardo Mondlane, a matter of contention with Frelimo's detractors. Alongside the imagined, teleological projections of state-building, Mozambican post-independence nationhood tended also to look back to the military glory of Independence Struggle as colonial/anti-colonial manicheism, and to look outwards to defending national boundaries against direct and indirect South African aggressions.

The urgency of defining the nation intensified in fairly immediate correlation with the urgency of defending it, as the Marxist-Leninist state was placed in crisis in the 1980s by the rise of Renamo, the Resistência Nacional Moçambicana. Founded in Rhodesia and subsequently operating as an instrument of South African destabilization, Renamo also became a focus for anti-Frelimo peasant dissent where it existed. Where there was no obvious nucleus of discontent with Frelimo, and in traditional Frelimo strongholds notably in the south of the country, Renamo had recourse to notoriously brutal and widely attested forced recruitment campaigns. ${ }^{6}$ Renamo's ideological self-presentation, especially abroad, played heavily on their adherence to a (black) national agenda in opposition to Frelimo's multi-racial Marxist internationalism. Frelimo government discourse was therefore increasingly driven to recuperate and reinvest the conceptual initiative of "nationhood" per $s e$, as cultural and spiritual force for the continued mobilization of social voluntarism and national defence. One significant consequence of this mobilization of nationhood in the face of external destabilization and encroaching internal collapse was the need for Frelimo as a primarily urban vanguard intellectual party to find means of increasing its popular appeal and reinforcing its concept of national citizenship among the people.

The title of the collection, Dumba Nengue, invokes the inverse of a homeland, a locus of violent displacement. Literally meaning "trust your feet" and more figuratively "run for your life", the phrase "dumba nengue" also denotes the illegal, parallel markets which are typically set up in informal refugee settlements. Peasants who witnessed horrific events were terrorized into abandoning the progressive, socially functional villages, which were Frelimo's model objective to endure a hand to mouth refugee existence, also leaving their land and thus threatening the productivity and stability of the country. The survivors of Magaia's accounts live in temporary settlements such as these in areas nicknamed "Dumba Nengue", along the main National Highway periodically risking death at the hands of the Renamo "bandidos" to go back to their lands and harvest their crops in order to get money for essentials. ${ }^{7}$

Where the "national" boundaries to be defended are precisely internal, village boundaries, resisting Renamo infiltration and attack, the survival of the nation becomes a statement of internal solidarity at a localized, community level, as against the large scale, epic grand narratives of Independence Struggle. The stability of the villages depends on their inhabitants being safe to continue living out their public adherence to the Frelimo ideals, which the communal villages and their basic infrastructures represent. Working against the depopulation of the villages and the undermining of the state's rural policies, Magaia's work exemplifies what George Yúdice terms in the Latin American context "top down" testimonial, as an "attempt on the part of the state to consolidate a national subject by means of the testimonial process" (45). At the same time, however, it also adopts many of the strategies which Yúdice regards, in counter-distinction, as specific to mediated or collaborative works of testimonial as acts of grass roots narrative praxis, exemplifying "the practical aesthetics of solidarity, of community building" (57). Yúdice usefully emphasizes the priorities of testimonial discourse as telling the truth in order to denounce urgent and 
immediate atrocity, and communicating this immediacy by remaining close to popular oral sources (44). I argue that in addition to achieving the type of international solidarity which informs Yúdice's readings of Latin American testimonios, Dumba Nengue also draws on his "practical aesthetics of solidarity and community building" (57) at a putatively national level. Expanding, then, Yúdice's specific and useful deployment of the term "aesthetic", the (national) subjects of Magaia's Mozambique try to "rework their identity through the aesthetic" (46) of solidarity as the act of telling. Using a metonymic rather than a metaphorical structure of representation this aesthetic of solidarity disseminates rather than arrogates subjective power and heroic status on the basis of individual experiences and choices, in relation to communal, village life.

Where Magaia's strategy of representation is metonymic, "the part for the whole", rather than metaphoric, the "one for the other", the maternal signifies differently from in ethnic or other classic forms of African nationalist poetics, and the metonymic, largely gender-neutralized body is not intrinsically bound up with essentialist maternal imagery. Elleke Boehmer in her study of gendered nationalism has associated the masculine with metonymic, specific and contiguous relations, as against the purely metaphorical role usually allotted to women in the nationalist scenario (6). While kinship clearly retains rhetorical value as a category of identification, and frequently as the focus of the tragedy in Dumba Nengue, the family is represented mainly as social, affording women as well as men a metonymic role, in Frelimo's organicist conceptualizing of family and society. From the late 1970 s onwards, the family was officially considered by Frelimo to be "the basic cell of society" (Arnfred 10). Women, particularly mothers, were considered to be the principle dynamizers of this family cell, although official Frelimo discourse emphasized women's historical and socio-cultural condition (i.e. uniformly oppressed along with men by colonial capitalism) over their biological condition (i.e. oppressed by men under patriarchal systems). This does not, of course, mean that in practice the Frelimo policies for women were not essentialist by omission, precisely because Machel's Engelsian view of female oppression within and by capitalist systems of wealth production and inheritance, allowed little or no analytical insight into sexual difference or the politics of reproduction. ${ }^{8}$ The opposition of sick body/healthy body largely replaced the male/female binary in the discursive constructions passed down from Samora Machel. Viewed as principles of connectivity rather than as "wombs of the nation" or points of origin in the socio-political body, women took on a false neutral, male normative metonymic role, and tended to be figuratively incorporated into organic images of healthy cells and functional bone structures. For example, in his famous 1973 Opening Address to the newly established Frelimo Women's Organization (the OMM), Machel envisaged the OMM as "um membro do corpo harmonioso da nossa família revolucionária" (Machel 35). Conversely, the earlier LIFEMO women's movement, "sem empenhamento, sem tarefa, [...] estava condenada a definhar, a tornar-se anémica e morrer" (Machel 17).

Conceptualising the body of the state in terms of non-gender specific anatomical imagery, allows for individuals, groups and communities to be described in terms of flexible, instrumental structures, emphasizing a metonymic sense of belonging and a transferability of roles. In their 1984 study, Isaacman and Stephen refer to the $8^{\text {th }}$ Session of the Frelimo Central Committee in 1976 defining the "aldeia comunal" as the "espinha dorsal do desenvolvimento das forças productivas das áreas rurais" (66). Demonstrating the transferability of such metonymic figures, this role is subsequently extended to women in the strong Frelimo provinces whose power in the communal villages could then be usefully reproduced at the level of the Party Cell. As Isaacman and Stephen express it, "visto que em Gaza, uma grande parte da população vive em aldeias comunais e as mulheres são a espinha dorsal dessas aldeias, é lógico que sejam igualmente a espinha dorsal das células do Partido 
aí estabelecidas" (34). Magaia's maternal positioning, operates in similar socially metonymic terms, as an active figure of inclusion and transferability, as against the fixity of individualistic, metaphorical rarification. Building from her own example of solidarity with the people, she becomes an ethical figure of conscious identification and active responsibility ${ }^{9}$ representing women in various forms of kinship and social connection apart from the maternal one, as sisters and wives, friends and neighbours.

In the context of the war, the Frelimo model of family/community as the base unit of society, takes on a new and intensified meaning, as a community re-made national through the unifying experience of suffering. The physical experience of Renamo violence binds those who have been its victims into a single national embodiment in relation to which Magaia herself carefully avoids playing the "mater dolorosa" role. In her introduction, it is not her own child that has been killed but, as she implies, it could have her own, or anyone else's. In this opening passage, Magaia declares her solidarity with women as real mothers of children, by narrating a true story of bringing her children a bag of tangerines as a treat from a shopping trip in Maputo. ${ }^{10}$ When she arrives home, she realizes that the tangerines are covered in blood, because she has just witnessed the violent death of a little girl whose blood soaked her car and her shopping. This one murdered child becomes the "filhos de Moçambique" as her blood joins the "sangue de filhos de Moçambique. Sangue vertido das chagas abertas nos seus corpos por baionetas e punhais ativados por filhos de Moçambique vendidos aos inimigos de Moçambique" (4). The blood images in this opening section unite victims of terror, outside, beyond and across the shattered relations of real family kinship which typify the war, into a collectivity based on suffering, courage and sacrifice. The ultimate consanguinity is now of blood shed not of blood shared. If the war's victims are Magaia's figurative children, the Renamo perpetrators are also sons of the same land, "filhos da Manhiça, de Inhambane, de Sofala,... de Moçambique..." (5), excluded from Magaia's interpellation of the national family, as abject, anti-patriotic "anti-bodies" in relation to the Frelimo "body" united by its suffering. Although Magaia frequently refers to the external "enemies of Mozambique", the predominant focus of Dumba Nengue remains the internal "domestic" division wrought by the Renamo "bandidos", at the level of homes, villages and communities.

Magaia draws on a wide variety of testimonial subjects, the majority of whom are adults not children, and who include peasants and agricultural workers, railway workers, teachers, a priest, militiamen, wives, sisters, mothers, and former mine workers. Thus, rather than arrogating a single monolithic truth to her own persona, Magaia invites the reader to synthesize a material truth of experience, from the commonalities linking the multiple narratives she relays. What stands out in the accounts is the similarity of the Renamo attacks building into a systematic regime of terror and prompting a national counter-discourse of redoubled resistance, which Magaia uses in her closing statement, to challenge the dominant truth claims of news reporting in the British, North American and South African media.

Deliberately eschewing the conventions of news reporting, the stark linguistic economy of each story in Dumba Nengue ironizes the banality of the violence visited upon the peasants. The unmaking of rational meaning constantly invokes the erosion of determinacy through a careful calculation of the absurd. The moment of horror is always relived as a shock experience, focusing not only on the fact that people are killed but also on how they are killed and on the epistemic violence that this does to socio-symbolic meaning. Magaia's narrative representation of fractured community sociality owes much to a Lacanian conceptualizing of the real, as that which "always comes back to the same place" (42), a kind of Aristotelian "tuché" or chance which interrupts the seamless surface of symbolized representation. For Lacan, the constant return of this "real" within the dream is the underlying structure of trauma as a repetition, with no past or future, no beginning or end. 
Read in sequence the stories of Dumba Nengue, simulate the process of traumatic repetition through the constant uncanny return of a singular moment when the "bandidos" breach the home or the village, and perpetrate an act of horror. " Renamo practices of the "grotesque", such as putting exemplary mutilated bodies on display, or forcing people to cook and eat their own slaughtered relations, effectively do extreme violence to the socially determined boundaries, which constitute the village-nation. The repeated trauma of the real, the uncanny aura of sameness, which connects the stories is the act of atrocity, which prevents terrified and alienated survivors from rebuilding any future sense of community. What "returns" in each of these stories, is precisely the impossibility of return to the village as it was, and thence to any historical past or national future. The "dumba nengue" phenomenon as the antithesis of Frelimo villagisation, isolates the people from both their collective history and their projected future, precisely the twin axes which enable the plotting of a nation from a village Mozambique.

In the face of wartime incursions, the village and its inhabitants metonymize the national boundaries of the Frelimo state in terms of the body. As Carolyn Nordstrom indicates, the body is conventionally associated with the state and state institutions through the figure of the "body politic" ("Backyard Front" 267). Dirty war acts of violence involving the dismembering and mutilation of the body may serve as a weapon of terror to undermine not only individual determinacy but also the legitimacy of a given state as body politic, to define and enforce accepted boundaries of what is "right". In Nordstrom's words, "severing the actual boundaries of human bodies through maiming and torturing can simultaneously serve to portray an assault on the boundaries of the body politic" ("Backyard Front" 267). This scenario is, as Nordstrom notes, further complexified in the Mozambican case where terror tactics are primarily adopted not by the state or by state institutions but by an insurgent guerrilla movement, aiming to undermine the state embodied in the village community at grass roots level. This description of the village as body politic informs Magaia's assertion in her introduction that, "os assassinos (que foram introduzidos pelos nossos inimigos) trituram a carne do Moçambicano" (6). Similarly, evoking the impaling of the national body, "um Jovem, um Assassino" begins, "são muitos os caminhos que eles usam para penetrarem no seio da população a quem intimidam com as suas armas de fogo e armas brancas" (29). The village attack becomes a penetration into the very bosom or heart of the body of the "people". In this context, the integral borders of every single Frelimo village community in Mozambique, and of every person murdered or disfigured within it, function as metonymic substitutions for the body politic of the nation-state.

Where the boundaries between personal and political, private and public, are constantly being unmade and redrawn by terrorist manipulations of the grotesque, the private acts of daily domestic life undertaken by women become a form of non-epic public heroism, reinstating sociality as the reintegrated body of the state. Nordstrom analyzes the structure of the "grotesque" as violation of socially symbolic physical limits whereby "undermining the determinacy of existence [...] is a lethal play of power and politics aimed at alienating the individual from the society at large, and thus from a basis for political resistance and change" (War Story 163). Reversing the indeterminacy of the grotesque as anti-national strategy, means re-asserting former, culturally sanctioned public and private boundaries, thus specifically intensifying the socially constitutive role of women, on which Frelimo already largely depended. As Nordstrom points out, "women are the lynch pins of basic domestic institutions, those constituting the very fabric of society and culture in their most fundamental form [so that] dirty war selection of them as central strategic targets is an attack aimed at dismantling the viability of a functional society itself ("Women and War" 8 ). The words and acts of women provide the last line of symbolic defence for the village as "imaginable" community. 
Magaia herself suggests this in her story "O poço prenhe" in which an old woman who has been driven out of her cooperative village Kamaxekana, feels an overwhelming nostalgia to return and to draw water from the much prized well which symbolizes the village's former unity and relative prosperity. The reader accompanies the woman's return step by step though the repetition of the word "viu" as she sees the house, the trees, and the well. The moment of seeing the well forms a silent ellipsis in the text, as the woman recoils in horror traced in reverse parallel through the repetition of "diz", only recounting retrospectively that the well is full of severed heads. No longer providing the life-giving water which the woman had remembered as the essence of "home", the well becomes the grotesque and deadly parody of pregnancy, which gives the story its title, and which effectively, literally, truncates any sense of a village future.

Magaia's counter-narrative gathers impetus through stories of effective resistance, which punctuate Dumba Nengue, with examples and inspirations. Reversing the anticommunitarian cycles of terror through a return to the repetitious rhythm of daily life and identity, these stories overturn the static, paralyzed repetition of trauma as a moment of interruption frozen in time. They also return the trauma victims to a sense of history as chronological movement, suggesting progress, change and the possibility of a future, as the imaginary space in which a Frelimo nation can still be envisioned. My paper concludes with three different examples of a "returning to the same place", as re-envisioning the future village/nation, in which women actively recreate violated boundaries, defying the permanently suspended time span of trauma.

The most extreme case of imposing restitutive meaning, concerns a revenge killing. In the shortest story in the book "Ilda odiava tanto os que mataram o irmão que ninguém a pôde parar" (83), Ilda performs a killing, which imitates her brother's violent death. Both Ilda's original act and Magaia's retelling of it, function as a warning to Renamo, bringing a communal sense of closure to the death of the brother, mentioned only at the end of the story as if incidentally, after the reader/viewer has registered the shock of Ilda's act. Ilda is standing in a crowd of people watching captured Renamo "bandidos" being brought in by the army. Seized by an impulse of anger, Ilda picks up a huge rock and crushes the skull of a prisoner in ironic replication of the way in which the "bandidos" had killed her brother, beating his head in as if they were "pilando" or pounding grain, the traditional work of women. By unconventionally using a huge rock as weapon, Ilda has similarly breached a socio-cultural boundary, both avenging her brother and asserting the determinacy of herself and her community. Unlike many of the stories, this one receives no further political comment or explanation from the narrator. The opening phrase, "é pequenino isto que vou dizer aqui" (83) ironically inverts the potential enormity of the act it is about to narrate. As Magaia remarks, "ninguém viu donde surgiu a pedra enorme que [Ilda] empunhou com força" (83) but the implication is that everyone was watching, and the shared spectacle of a restitution has restored a sense of community.

In "Madalena voltou do cativeiro", a fourteen-year old girl Madalena who had been kidnapped and raped by Renamo as preparation to act as a "comfort woman", returns to her home community following her successful escape. Madalena's youth and vulnerability are emphasized, thus denaturalizing her violent, sexual treatment by Renamo. She is reintegrated into appropriately protective adult-child relations symbolized by her own female relatives, but also by the Frelimo officials who initially take care of her, and whose roles significantly overlap with those of her family. The halting account of her terrible experiences, told to the Frelimo Brigade Commander, is interwoven with the counter-narrative of her happy return to her community. Picking up the various threads of shattered family life, local village history, and the heroism of Frelimo national independence struggle, evoked through Madalena's father who had been a Makonde guerrilla, the story culminates with a dance of welcome, the 
most confident and unguarded form of shared social expression. Spared future rape and humiliation, as the closing assertion makes clear, "nunca mais te encontrarão" (17), Madalena will implicitly follow her mother and grandmother in perpetuating socially sanctioned forms of kinship as against the Renamo practice of maintaining girls as enforced "comfort women".

The last of the three stories shows how the "dumba nengue" scattering of communities leaves individuals paralysed by a sense of radical anomy, which is most intensely experienced as a lack of respect for ancestors and the absence of proper burial rituals for the dead. In this sense too, the shared remembrance afforded by testimonial narrative works to reverse the alienating erosion of shared meanings based on collective memory. Magaia counters all the non-burials and grotesque abuses of the dead related in Dumba Nengue, by devoting her longest and most detailed story to one single communal village funeral, the only one described in the whole volume. The four-part account which makes up "Vida e Morte de um Combatente" was also, significantly, the only one of Magaia's original chronicles to appear in Tempo after the coverage of Samora Machel's death and state funeral rites. ${ }^{12}$ Thus, in its original frame of reading "Madala Makana", the "Combatente" of the title, a village "secretário" killed leading a volunteer defense militia in 3 de Fevereiro, ${ }^{13}$ becomes a local, community-scale version of Samora Machel, the military architect of the Mozambican nation. An explicitly exemplary parable, the story gives brief, dramatic scenes from the life, work and death of Madala Makana. His heroic death inspires the village to stay and defend itself, rather than flee in the face of Renamo attack. Funeral remembrance becomes a literal re-membering in which villagers renew their allegiance to the community principles of solidarity and voluntarism, which were embodied in the body of Madala Makana. ${ }^{14}$

The body of the village itself resists the intrusion of the Renamo attack as "o bandido não conseguiu penetrar na Aldeia" (70) but a bullet brings down Makana, and he is then killed by a "bandido" cutting into his throat. Madala Makana's body is left on view during his funeral but the mutilative act of cutting his throat, is negated by having "a sua garganta enrolada num pano branco" (71). A symbolic severing of the head, the decapitating of the body as community, is converted into a reintegrating of bodily identity. The villagers fear that the bandits will return to find Makana's place of burial and desecrate his body. Immediately following the burial, warning arrives of a new bandit attack, prompting a young woman who is carrying a child on her back to stir the people to self-defence announcing, "“estão a tentar assustar-nos para que abandonemos a Aldeia. Mas nunca o faremos. Madala Makana ensinou-nos a viver como gente nesta nossa aldeia e se a abandonássemos não 0 amaríamos como ele o merece, por isso ficamos aqui"" (75).

The woman's voice in this story uses the funeral ritual, much as Magaia herself uses Dumba Nengue in her dedication to the memory of Samora Machel, as the new starting point for an aesthetics of solidarity based on identifications of collective love and remembrance, connecting the various stories into an imagined national community of readers and speakers who have witnessed or experienced similar phenomena, and made similar choices as a result. Although the book's impact was limited to a literate readership, the broad representativity of Dumba Nengue in other regions of Mozambique was movingly attested in a letter published in Tempo, sent by a reader from Beira named David Langa. He wrote, “'Dumba Nengue' é um livro de todos nós, foca as inúmeras situações em que Manhiça e o seu povo viveram. Lina Magaia falou da Manhiça mas também podia ter falado de Kanda, Tsikiri, Mucilbezi (em Sofala) ou Matimule, Chidenguele, Nhanzilo (em Gaza)...". ${ }^{15}$

As a female authorized work of witness, Dumba Nengue, presents itself as a model for disseminating rather than arrogating the power of testimonial speech, as a means of transforming trauma and victimhood into the authority of somatic experience, re-membering the disfigured body politic of community. Magaia's decision to authorize her own narrative 
through maternity, as a category of social and ethical identification provides the figurative field for a testimonial aesthetic of national solidarity, which is broadly addressed, metonymic and elective. In this respect, Magaia demonstrates how a woman writing in the postIndependence period could contingently hijack the legitimizing master discourses of both national independence and Frelimo state ideology, to articulate the participative ideal of a citizens' Nation, which could also account for the specific, localized experiences of women.

\section{NOTES}

I would like to thank the Arts and Humanities Research Board for funding my research leave in 1998 and the British Academy and Sir Ernest Cassel Educational Trust for funding the trip to Mozambique in 1999, which enabled me to conduct much of the research for this paper. My thanks are due to Lina Magaia for meeting me in Maputo in September 1998, and to Paulina Chiziane for facilitating this meeting. I am also indebted to Till Geiger for his valuable comments on earlier drafts of this paper.

${ }^{1}$ A Frelimo member since the Struggle for Independence (1964-75) and coming from a prominent political family, Lina Magaia became deputy director for the Maragra state sugar farm in Manhiça, Maputo province in 1982 and subsequently Director of Agricultural Development in 1986. Throughout this time, she maintained the vigorous output in committed journalism, which had begun during the anti-colonial resistance years of her youth. Her weekly column reporting "da Manhiça" appeared in the national daily Noticias in the 1980s and she also produced regular reports, "crónicas" and travelogues for Tempo. See Nancy Murray's interview with Lina Magaia in Race and Class, 1989.

${ }^{2}$ Ten of the twenty-two chronicles, which make up Dumba Nengue originally appeared in the Tempo series. Where there is a significant difference in title, I have given the title in the published collection in square brackets. The dates were as follows: "A menina que nem sonhos tinhas", "A isto chamaram vingança" and "O Massacre de Junho no Cemitério da Manhiça." no. 831. 14 September 1986, 8-9, "Madalena voltou do cativeiro." no 832. 21 September 1986, 6-7, "E assim o irmão de Julieta foi "baptizado"” and "O bandido quis entrar em Calanga." no 833. 28 September 1986, 6-7, "Pilaram-lhes as cabeças como se fossem amendoins", "Porque artes e manhas, não sei, mas fizeram daquele jovem isto" [reprinted as "Um jovem, um assassino"] and "Lá está o poço prenhe." no. 835. 12 October 1986, 9-11, "Vida e morte de um combatente", parts 1, 2, 3. no. 840. 16 November 1986, 57 and "Quatro momentos na vida de um combatente", part 4. no. 841. 23 November 1986, 89.

${ }^{3}$ The international role which Dumba Nengue played in denouncing Renamo atrocities is well-attested by its inclusion in most political and sociological studies of the war, and is therefore not the focus of the current study.

${ }^{4}$ See Urdang 1984, 1989, 1995, Arnfred, Sheldon, Isaacman and Stephen.

5 As Eduardo Mondlane described it, "Moçambique era uma invenção portuguesa, dentro da qual a experiência comum de opressão e dominação dos africanos conduzira ao despertar duma identidade nacional moçambicana" (Elísio Macamo 36).

${ }^{6}$ Carolyn Nordstrom's ethnography of the war, A Different Kind of War Story is suitably cautious about the politicization of war statistics, but states: "in addition to the one million killed, one-third of all hospitals and schools were destroyed; and the damage to economic viability is incalculable. And all this by only 30,000-60,000 troops" (13) and subsequently "over one million Mozambican war refugees (refugiados) fled to neighbouring countries, two million people were displaced within Mozambique (deslocados), and an 
additional two and a half million people have been directly affected by the war (afetados), meaning that violent conditions destroyed their ability to produce sufficient food or live a normal life-style. Altogether, the lives of one-half of the country's inhabitants have been seriously disrupted by the war" (40).

${ }^{7}$ Magaia explains her own specific use of the term in the story "'Dumba Nengue' ou as Riquezas Abandonadas" (76-81).

${ }^{8}$ For the Frelimo foundational text on the status and role of women, see Samora Machel's $A$ libertação da mulher é uma necessidade da revolução, garantia da sua continuidade, condição do seu triunfo. Porto: Textos da Revolução/2, 1974.

${ }^{9}$ Susan Geiger takes a similar view in her reading of Tanganyikan women in early nationalist organization when she writes, "an essentialist reading of African women's deployment of motherhood and fertility denies them the possibility of symbolic and metaphoric speech" (79n).

${ }^{10}$ Perhaps with a view to contextualizing for the anglophone reader, Magaia's text in Michael Wolfer's English translation begins differently from the original with a longer introduction to Magaia's family. She explains that she has three children by birth and a fourth by adoption, and brings home to her son the horror she has just witnessed by comparing the child just killed, with her own daughter Sonyka.

${ }^{11}$ My use of the Lacanian concept of the Real in this context is indebted to John Beverley's analysis of the shock effect, which, he identifies as common to testimonial writing, and elaborates in "The Real Thing". Beverley reads this Real as that which "resists symbolization [...] that which collapses the claim of any particular form of cultural expression to representational adequacy and value" (273). Beverley does not, therefore, see this Lacanian Real as an absolute category but rather as a relational one "historically, socially and psychically specific" so that "there are different Reals for different Symbolics" (273). In this sense, the restoring of socio-cultural boundaries in Magaia's text requires a precise reversal of the particular effect of a given Real.

${ }^{12}$ Narrating the many deaths of the people in a volume dedicated to remembering the single death of their national leader, Magaia reflects Ernest Renan's sense of spiritual unity and common consent in "What is a nation?" as he writes, "suffering in common unifies more than joy does. Where national memories are concerned, griefs are of more value than triumphs, for they impose duties and require a common effort" (19).

${ }^{13}$ As Allen Isaacman explains in his introduction to the English translation of Dumba Nengue (80), the name 3 de Fevereiro, was quite often given to Mozambican communal villages and commemorates the date in 1969 when Eduardo Mondlane was assassinated in Dar-es-Salaam. See also Stephanie Urdang 1989. As a journalist working in collaboration with Lina Magaia, Urdang visited this particular 3 de Fevereiro in the 1980s. Chapters 5 and 6 of And Still they Dance, "Transforming the Countryside" and "Contradiction and Change", relate her observations there, studying the changes in women's work patterns and the effects on Renamo attacks on modernization programs.

14 "Re-membering" has become a relatively widespread metaphor for testimonial and other memorial processes, which reconstitute in narrative the bodies and lives of those literally dis-membered by torture and disfiguration. In "Re-membering the Dead. Latin American Women's 'Testimonial' Discourse”, Nancy Saporta Sternbach uses the term with specific reference to the Madres de Plaza de Mayo, and women's use of Roman Catholic regeneration/resurrection discourses to figure physical transubstantiation to wholeness (94; 98). Carolyn Nordstrom as we have seen, uses the same term rather differently in the Mozambican context, seeing acts of dis-memberment as violent specular statements of exclusion in relation to the body politic of the state, figured in the wholeness of the body ("Backyard Front" 267). Nordstrom's use of the term comes closest to reflecting my own in 
this context, but the specific relationship of women testimonial writers to discourses of remembering warrants further study.

${ }^{15}$ See "Cartas dos Leitores", Tempo, 26 de Julho de 1987, 35.

\section{WORKS CITED}

Arnfred, Signe. "Women in Mozambique: Gender Struggle and Gender Politics." The Review of African Political Economy, 41 (1988): 5-16.

Beverley, John. "The Real Thing." The Real Thing. Testimonial Discourse in Latin America. Ed. Georg M. Gugelberger. Durham and London: Duke University Press, 1996. 266-86.

Boehmer, Elleke. "Stories of Women and Mothers: Gender and Nationalism in the Early Fiction of Flora Nwapa." Motherlands. Black Women's Writing from Africa, the Caribbean and South Asia. Ed. Susheila Nasta. London: The Women's Press, 1991.

Geiger, Susan. TANU Women. Gender and Culture in the Making of Tanganyikan Nationalism, 1955-1965. Social History of Africa. Portsmouth: Heinemann, 1997.

Hall, Margaret and Tom Young. Confronting Leviathon. Mozambique since Independence. London: C. Hurst and Co., 1997.

Isaacman, Barbara and June Stephen. A mulher moçambicana no processo de libertação. Maputo: Instituto Nacional do Livro e do Disco, 1984.

Lacan, Jacques. The Four Fundamental Concepts of Psychoanalysis. Ed. Jacques-Alain Miller. Trans. Alan Sheridan. New York: Norton, 1978.

Langa, David. "Dumba Nengue.” Cartas dos Leitores. Tempo (26 July 1987): 35.

McClintock, Anne. Imperial Leather: Race, Gender and Sexuality in the Colonial Contest. New York and London: Routledge, 1995.

Macamo, Elísio. "A influência da religião na formação de identidades sociais no sul de Moçambique." Identidade, Moçambicanidade, Moçambicanização. Ed. Carlos Serra. Maputo: Livraria Universitária, Eduardo Mondlane, 1998. 35-64.

Machel, Samora. A libertação da mulher é uma necessidade da revolução, garantia da sua continuidade, condição do seu triunfo. Porto: Textos da Revolução/2, 1974.

Magaia, Lina. Dumba Nengue. Histórias trágicas do banditismo. Autores Africanos 26. São Paulo: Editora Ática S.A., 1990.

- Dumba Nengue. Run for your Life. Peasant Tales of Tragedy in Mozambique. Trans. Michael Wolfers. Intro. Allen Isaacman. Trenton N.J.: Africa World Press, 1988.

Murray, Nancy. "Mozambique: the revolution and the bandits: an interview with Lina Magaia." Race and Class. A Journal for Black and Third World Liberation. 30. 4 (April-June 1989): 21-29.

Ngoenha, Severino Elias. "Identidade moçambicana: já e ainda não." Identidade, Moçambicanidade, Moçambicanização. Ed. Carlos Serra. Maputo: Livraria Universitária, Eduardo Mondlane, 1998. 17-34.

Nordstrom, Carolyn. "Women and War: Observations from the Field." Minerva: Quarterly Report on Women and the Military IX.1 (Spring, 1991): 1-15.

- . "The Backyard Front." The Paths to Domination, Resistance and Terror. Eds. Carolyn Nordstrom and JoAnn Martin. Berkeley: University of California Press, 1992. 260-74.

- A Different Kind of War Story. Philadelphia: University of Pennsylvania, 1997.

Renan, Ernest. "What is a Nation?" Nation and Narration. Ed. Homi K. Bhabha. London and New York: Routledge, 1990. 8-22

Serra, Carlos. "Prefácio." Identidade, Moçambicanidade, Moçambicanização. Ed. Carlos Serra. Maputo: Livraria Universitária, Eduardo Mondlane, 1998. 9-12. 
Sheldon, Kathleen. "Women and Revolution in Mozambique. A Luta Continua." Women and Revolution in Africa, Asia and the New World. Ed. Mary Ann Tétreault. Columbia: University of South Carolina Press, 1994. 33-61.

Sternbach, Nancy Saporta. "Re-membering the Dead. Latin American Women's 'Testimonial' Discourse." Latin American Perspectives 70. 18. 3 (Summer 1991): 91102.

Urdang, Stephanie. "Women in National Liberation Movements." African Women South of the Sahara. Eds. Margaret Jean Hay and Sharon Stichter. New York: Longman, 1984.

Women and the New Mozambique and Women in a Communal Village. New York: Women's International Resource Exchange (WIRE) Service, 1984.

- And Still They Dance. Women, War, and the Struggle for Change in Mozambique. London: Earthscan Publications Ltd., 1989.

Yúdice, George. "Testimonio and Postmodernism." The Real Thing. Testimonial Discourse in Latin America. Ed. Georg M. Gugelberger. Durham and London: Duke University Press, 1996. 42-57. 